\title{
Multiple phylogenies reveal a true taxonomic position of Dulcicalothrix alborzica sp. nov. (Nostocales, Cyanobacteria)
}

\author{
Bahareh Nowruzi ${ }^{1} \&$ Sergei Shalygin ${ }^{2 *}$
}

\author{
${ }^{I}$ Department of Biology, Science and Research Branch, Islamic Azad University, Daneshgah Blvd, Simon \\ Bulivar Blvd, Tehran, Iran \\ ${ }^{2}$ Plant and Environmental Sciences Department, New Mexico State University, 945 College Drive, Las Cruces, \\ New Mexico, 88003 USA; *Corresponding author phone: +1(575)339-99-09, e-mail: sshalygin18@jcu.edu
}

\begin{abstract}
A new species of heterocytous cyanobacterium Dulcicalothrix alborzica sp. nov. (Calotrichaceae) was isolated from Iran and described following a polyphasic approach. Morphological examination indicated that the strain, initially called "Alborzica", belonged to the genus Calothrix. Nonetheless, 16S rRNA gene analysis showed that "Alborzica" were within the Dulcicalothrix cluster. In order to confirm the taxonomic position of this new taxon, rbcL and rpoC1 phylogenies were inferred. Results confirmed identity of "Alborzica" supporting the 16S rRNA phylogeny. Analysis of the secondary structures of 16S-23S Internal Transcribed Spacer (ITS) revealed that "Alborzica" had unique structure compared with known Dulcicalothrix spp. Therefore, based on the morphology and thorough molecular analysis, "Alborzica" should be considered a novel species in the genus Dulcicalothrix.
\end{abstract}

Key words: new species, polyphasic approach, rbcL, rpoC1, 16S-23S ITS

\section{INTRODUCTION}

Cyanobacteria are ancient oxygenic photoautotrophs and it is evident that the chloroplasts of plants and algae are derived from a cyanobacterial ancestor, hence they are considered as the linchpin of plant evolution (GOULD et al. 2008; MAREš et al. 2019). Cyanobacteria are a particularly challenging group to classify and their systematics have been under constant revision (HoffMAnN et al. 2005; KomÁreK et al. 2014). Traditional classification system were thought to be inconsistent by many researchers, as it did not depict the true phylogenetic history within the cyanobacterial lineage (ANAGNOSTIDIS \& KoMÁREK 1985; HoFFMANN et al. 2005; Johansen \& CASAMATTA 2005; ŘeháKová et al. 2007; Siegesmund et al. 2008). The advent of the electron microscopy and molecular techniques led to the reclassification of the conventional taxonomic scheme (Hoffmann et al. 2005; KomÁreK et al. 2014; MAREŠ et al. 2019). The classification system proposed by HoFFMANN et al. (2005), divides cyanobacteria into 4 subclasses, among which only Gloeobacteriophycidae and Nostochophycidae form monophyletic lineages. Nostochophycidae including order Nostocales is one of the most complex taxonomic group within Cyanobacteria due to the presence of unestablished type species of several genera like Nostoc Bornet et Flahault, Calothrix Bornet et Flahault and many others. The genus Calothrix, to which our strain initially was assigned, belongs to the order Nostocales, which was placed in the subsection IV according to outdated, strictly microbiological classifications (RIPPKA et al. 1979). Calothrix exhibits a notorious morphological heterogeneity and extreme polyphyly, which is evident from various independent clades in the phylogenetic trees of past research (Sinvonen et al. 2007; BERRENDERo et al. 2008, 2011; Thomazeau et al. 2009; BerRendero Gómez et al. 2016; ShaLygin et al. 2017, 2018).

Cyanobacterial researchers all over the world are adopting a polyphasic approach, according to which, information obtained from morphological observation is integrated with molecular and ecological data in order to resolve taxonomic dilemmas (Wilmotte \& Golubic 1991; Wilmotte 1994; KomÁreK \& KašTovskÝ 2003; CASTENHOlZ \& Norris 2005; TAton et al. 2006; Berrendero et al. 2008; Garcia-Pichel et al. 2013). Following this approach, SARAF et al. (2019), reestablished family Calotrichaceae and described new genus and species Dulcicalothrix necridiiformans Saraf et al. based on 16S rRNA phylogeny. In this study, many "Calothrix" 
species, including Calothrix desertica SchWABE, were assigned to Dulcicalothrix (SARAF et al. 2019). "Recreation" of the family Calotrichaceae seems to be premature in SARAF et al. (2019) since Calotrichaceae was established based on Dulcicalothrix sequence, and not based on type material of marine Calothrix confervicola Agardh ex Bornet et Flahault. Hence, the "true" Calotrichaceae remain unknown and family level taxonomy of Dulcicalothrix should be clarified.

In the present study, initial morphological examination indicated that "Alborzica" belonged to the genus Calothrix. However, molecular and phylogenetic assessment based on multiple gene trees showed that this strain is within the Dulcicalothrix clade. Herein, we are describing Dulcicalothrix alborzica sp. nov. as a novel taxon of recently described genus Dulcicalothrix, following recommendation of International Code of Nomenclature for Algae, Fungi and Plants (TurLand et al. 2018).

\section{Material And Methods}

Isolation and strain characterization. Cyanobacterial colonies were collected from submerged $(-30 \mathrm{~cm})$ pebbles, one meter from the shore of the bank of the Atrek River flowing through the Alborz mountains, Iran (Fig. 1). Biomass and in some cases small pebbles with visible natural populations were placed into the cone-shape plastic bottles and transferred to the laboratory for the subsequent isolation. Limnological parameters such as temperature, nitrate/phosphate concentrations, and $\mathrm{pH}$ were measured while sampling (Table S1). In the laboratory, an aliquot of the sample was spread onto $1.2 \%$ agar-solidified BG-11 $1_{\mathrm{o}}$ medium (RIPPKA et al. 1979). Subsequent transfers were repeated until a pure culture was obtained. Unialgal cultures were maintained in a 250 $\mathrm{ml}$ cotton-stoppered Erlenmeyer flask at $28 \pm 2{ }^{\circ} \mathrm{C}$ with periodic shaking (twice a day), illumination of ca. 50-55 $\mu$ E.m${ }^{2} \cdot \mathrm{s}^{-1}, 14: 10 \mathrm{~h}$ light: dark cycle. Morphological observations of the culture utilized an Olympus CX31RTS5 (Olympus, Tokyo, Japan) stereoscope equipped with a QImaging GO-3 digital camera (Teledyne QIMAGING. Surrey, Canada) and Olympus BX43 microscope equipped with manufactured Sc50 digital camera (Olympus, Tokyo, Japan).

A preliminary identification was done using the keys by DESIKACHARY (1959) with the revisions of KOMÁREK (2013). A detailed morphological analysis of the strain under study was performed. All diacritical features were observed and documented with 50-100 measurements for each parameter. A unialgal culture has been deposited in the Cyanobacteria Culture Collection (CCC) with the following accession number: CCC1387-b. Dried holotype material was deposited into ALBORZ herbarium with the following accession number: CCC1387-a. Both culture collection and herbarium are affiliated to the Science and Research Branch of the Islamic Azad University (Tehran, Iran).

Molecular methods. Genomic DNA was isolated from log phase cultures using HiPurA ${ }^{\circledR}$ Bacterial Genomic DNA Purification Kit (Cat ID: MB505, HIMEDIA, Mumbai, India) following the manufacturers instructions, except for the increase of incubation time for the lysis solutions
AL and $\mathrm{C} 1$, which were set to 60 and 20 min, respectively. Presence of DNA was confirmed with gel electrophoresis and NanoDrop. 16S rRNA, 16S-23S ITS, $r b c \mathrm{~L}$ and $r p o \mathrm{C} 1$ gene regions were amplified using the oligonucleotide primers listed in Table S2. PCR's were conducted with iCycler (BioRad, California, USA) applying $25 \mu 1$ aliquots containing 10-20 ng of DNA template, $0.5 \mu \mathrm{M}$ of each primer, $1.5 \mathrm{mM}$ of $\mathrm{MgCl}_{2}, 200 \mu \mathrm{M}$ of dNTPs, and $1 \mathrm{U} . \mu 1^{-1}$ of Taq DNA polymerase. The thermal profiles used in our PCR can be seen in Table S2. Amplicons were checked by $1 \%$ agarose gel electrophoresis (SeaPlaque ${ }^{\circledR}$ GTG ${ }^{\circledR}$, Cambrex Corporation). Sanger sequencing was performed on a 3730xl automated sequencer with 96 capillaries (Applied BioSystems, USA). Obtained sequences were analysed and curated by Lasergene Seqman (DNAStar, Madison, USA). Protein coding gene sequences were annotated with NCBI ORF Finder and the ExPASY proteomics server. All sequences were deposited in the DNA Data Bank of Japan (DDBJ) under the accession numbers shown in Table S3.

Phylogenetic analysis. The 16S rRNA, 16S-23S ITS, rbcL and $\mathrm{rpoC} 1$ gene sequences obtained in this study, as well as the highest hit sequences ( $>94 \%$ identity), were retrieved from GenBank (mostly tapered heterocytous species), were first aligned using MUSCLE (EDGAR 2004), and then maximum likelihood phylogenetic trees were inferred via IQ-Tree (NGuYEN et al. 2014). Different models (Table S3, last column to the right) were used as suggested (BIC criterion) after employing the model test implemented in IQ-tree. Tree robustness was estimated with bootstrap percentages using 100 standard bootstrap and 10,000 ultrafast bootstrap to evaluate branch supports (MINH et al. 2013). P-distance was calculated in MegaX (Kumar et al. 2018) and percent similarity was calculated with following formula: $\mathrm{s}=100 *(1-\mathrm{p}-$ value $)$.

16S-23S ITS analysis. ITS region was characterized according to the JOHANSEN et al. (2011). Comparison of the ITS secondary structures were generated using the Mfold web server, version 2.3 (ZUKER 2003) under standard conditions:

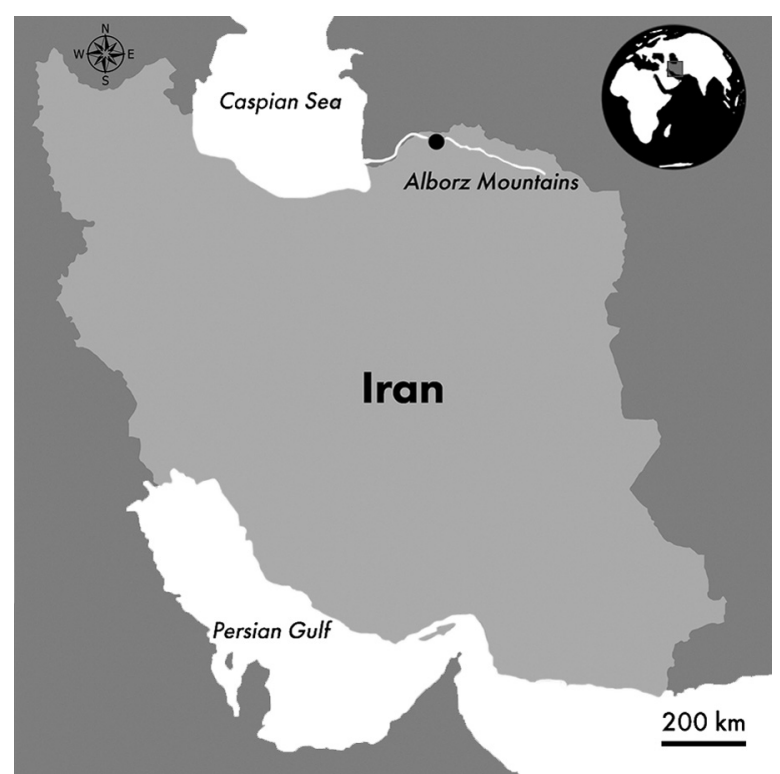

Fig. 1. Map-schema of the locality where Dulcicalothrix alborzica was found. Sample site indicated with black circle. 
untangled loop fix and the temperature set to default $\left(37^{\circ} \mathrm{C}\right)$.

Graphical design. Map-scheme was created using Adobe Photoshop 2019 (Adobe System Inc., San Jose, CA, USA). Line drawings of Dulcicalothrix alborzica was made usingPhotoshop 2019 utilizing Wacom Intuos PRO table pen tablet (Wacom Europe GmbH, Düsseldorf, Germany). All trees were visualized in FigTree version 1.4.4 and post edited in Adobe Illustrator 2019 (Adobe System Inc., San Jose, CA, USA).

\section{RESULTS AND DisCuSSION}

\section{Dulcicalothrix alborzica Nowruzi and Shalygin sp. nov.}

Diagnosis: Similar to many Calothrix species differ from those by presence of multiple short, isopolar/ heteropolar hormogonia encapsulated within a single sheath. Forms independent clade from any established Dulcicalothrix spp., based on 16S rRNA, rbcL and rpoC1 phylogenies. Additionally, different from type species of Dulcicalothrix in ITS sequence.

Description: In natural populations, form dark green or blackish spots on the surface of the submerged paddles. In cultures, form similar colonies on the agar surface. Filaments from short to long, more or less straight or wavy, usually with transparent, hyaline sheaths. Occasionally single collars observed in the middle part of the filaments. Sheaths tightly adherent to the edges of the cells, sometimes widened or onion-like swollen, always colorless. Trichomes, 7.0-7.5 $\mu \mathrm{m}$ wide at the middle, up to $8 \mu \mathrm{m}$ wide at the base. Single-, doublefalse, and geminate branching frequent. Trichomes gradually taper to the conical cells, without formation of the hairs, sometimes onion-like swollen in the base (8 $\mu \mathrm{m}), 7.0-7.5 \mu \mathrm{m}$ wide at the middle. Cells grey-green, granulated, of different shapes, mostly discoid $7.5 \times$ 3-4 $\mu \mathrm{m}$, sometimes without constrictions. Heterocytes single or two in the row, basal or intercalary, of different shapes and sizes: hemispherical or half-rounded, $6 \times 8 \mu \mathrm{m}$, rounded, $4.5 \mu \mathrm{m}$ or oblong $7.5 \times 4-6 \mu \mathrm{m}$. Necridia present.

Etymology: Alborzica. Adj. from Alborz, the name of a mountain range in northern Iran from where this species was isolated.

Type locality: Iran, Golestan province, from submerged pebbles in the bank of the River Atrek within Alborz Mountain Range ( $\left.37^{\circ} 55^{\prime} 48^{\prime \prime} \mathrm{N}, 55^{\circ} 37^{\prime} 05^{\prime \prime} \mathrm{E}\right)$.

Reference strain: Dulcicalothrix alborzica strain Alborz with following accession number: CCC1387-b deposited in the Cyanobacteria Culture Collection (CCC) at the Science and Research Branch, Islamic Azad University, Tehran, Iran.

Holotype here deposited: as a dried specimen in the herbarium ALBORZ at the Science and Research Branch, Islamic Azad University, Tehran, Iran under the following accession number: CCC1387-a.
DDBJ accession numbers: partial 16S rRNA: MH014811, 16S-23S ITS: MN168762, rpoC1: MH022745, rbcL: MH022746.

Morphological notes: The studied strain formed many different bright dark-green macroscopic colonies on agar surface. Under the light microscope, the filaments appeared to be curved. Trichomes had a firm sheath, not ending into hairs, sometimes opened at the apical end or in the middle (Fig. 2A). Heterocytes were basal, yellowish, single, rounded (Fig. 2B), hemispherical (Fig. 2D) or oblong (Fig. 3), intercalary heterocytes usually were found in pairs (Fig. 3). Sometimes, the basal parts of the trichomes were onion-like swollen (Fig. 2C). Often, base of trichomes were with conical terminal cells (Fig. 3E). Filament appeared to be branched due to the massive proliferation of hormogonia derived from the main filaments (Fig. 2B). Disintegration of filaments occured by hormogonia formation, with a subsequent increase in trichome width (Fig. 2C). Hormogonia consisted of relatively short series of the cells with tapering ends (Fig. 2A). In some cases, hormogonia were separated from the rest of the trichomes by a necridic cells (Fig. 2E and Table S4). Line drawing of the holotype material shown in Fig. 3.

Comprehensive phylogenetic analysis based on 16 rRNA gene sequences showed that the Dulcicalothrix alborzica Alborz is within a large cluster composed by terrestrial and freshwater Dulcicalothrix strains. There were at least 5 different "Calothrix" lineages outside of Dulcicalothrix clade with less than $\sim 90 \%$ identity to $D$. alborzica. Dulcicalothrix clade was phylogenetically distant from established Rivularia and Macrochaete clusters (Fig. 4, Fig. S1). Borders of Dulcicalothrix was defined based on the percentage similarity of $16 \mathrm{~S}$ rRNA gene according to which misidentified "Rivularia" sp. UAM 305 (EU009149), "Rivularia" sp. VP4 08 (FR798919), and "Calothrix" sp. NIES-4101(AP018280) were found to be outside of the genus with similarity values less than $96 \%$ (Table 1). Dulcicalothrix is a rich genus with several different clades, unfortunately there are only few species established so far from this group, D. necridiiformans and $D$. desertica (Fig. 4, Fig. S1). Strain under investigation fell into clade with the sequences from fresh and thermal waters: Dulcicalothrix sp. PCC 7715 (KM019959), and Dulcicalothrix sp. IAM M-261 (AB325536), which were coming from different locations. Following sequences from this group: Dulcicalothrix sp. D253 (X99213), and Dulcicalothrix sp. HK-06 (AB694935) most likely belong to a separate species based on the percent similarity which were below $98.8 \%$ similarity (Table 1 ). Geographic locations of those sequences were unknown or distant from D. alborzica (D253: unknown, HK-06: Japan, Nostoc commune crust). Strain D. alborzica was found to be closely related to Dulcicalothrix sp. PCC 7715 (KM019959), Dulcicalothrix sp. IAM M-261 (AB325536) and "Dulcicalothrix" sp. 9I (KU668908) 


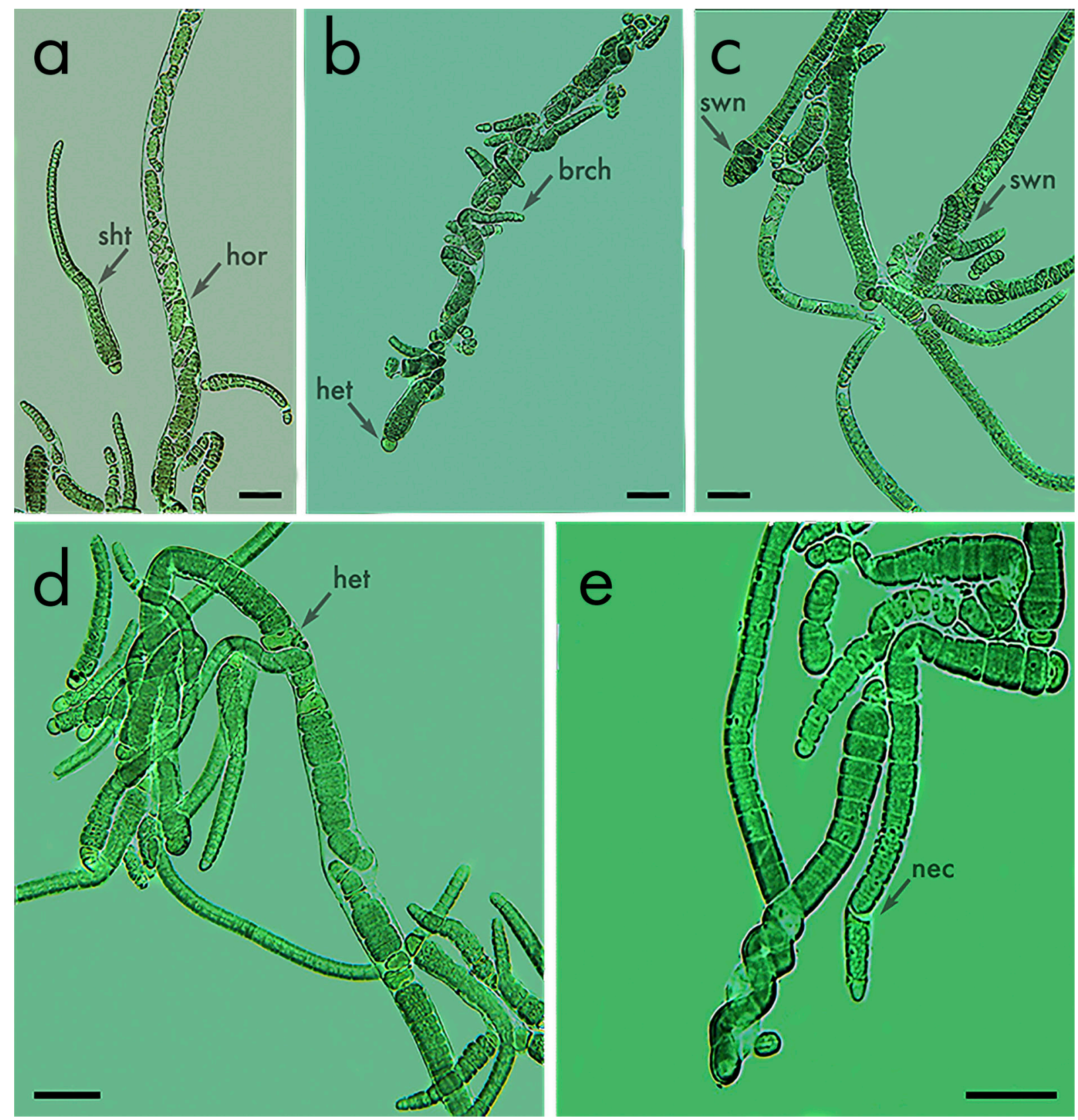

Fig. 2. Microphotographs of the new Dulcicalothrix alborzica isolated from Iran: (a) illustration of the sheath opening in the middle of young filament (left arrow), and mature filament with multiple short hormogonia inside (right arrow); (b) growing mature filament with short branching/waving heteropolar trichomes; (c) representation of the onion-swollen basal parts of the filaments indicated with arrows; (d) closed-up look on heterocytes and initial single-false branching; (e) illustration of the constrictions of the cells and necridia (arrow). Abbreviations: (sht) sheath, (hor) hormogonia, (het) heterocyte, (brch) branching, (swn) onion-swollen trichomes at the basal part, (nec) necridia. Scale bars $10 \mu \mathrm{m}$.

with percent similarity of $99.7-99.9 \%$. Likely, these stains either belong to one species or they are cryptic taxa. Since there is no $16 \mathrm{~S}-23 \mathrm{~S}$ ITS available for them, it is impossible to judge at this point. Interestingly, strain Dulcicalothrix sp. PCC 7715 (KM019959) formed two separate lineages, perhaps, indicating two non-identical ribosomal operons.

$\mathrm{RbcL}$ and rpoC1 phylogenies served as an additional line of evidence for the determination of a true phylogenetic position of the studied strain (Figs 5, 6; Figs S2, S3). Both of them placed D. alborzica into the clade sister to a large clade containing Aliinostoc, Nostoc and Desikacharya as previously shown on 16S rRNA phylogeny by SARAF et al. (2019). Draft genome and whole genome sequencing of $D$. alborzica and many other Calothrix-like strains will resolve family level taxonomy in this complex group. RbcL phylogeny grouped $D$. alborzica with $D$. desertica PCC 7102 (AB075906), D. necridiiformans V13 (KY863523) type species of the genus, and Dulcicalothrix sp. NIES-4071(AP018255) and others (Fig. 5, Fig. S2). All listed sequences were found on 


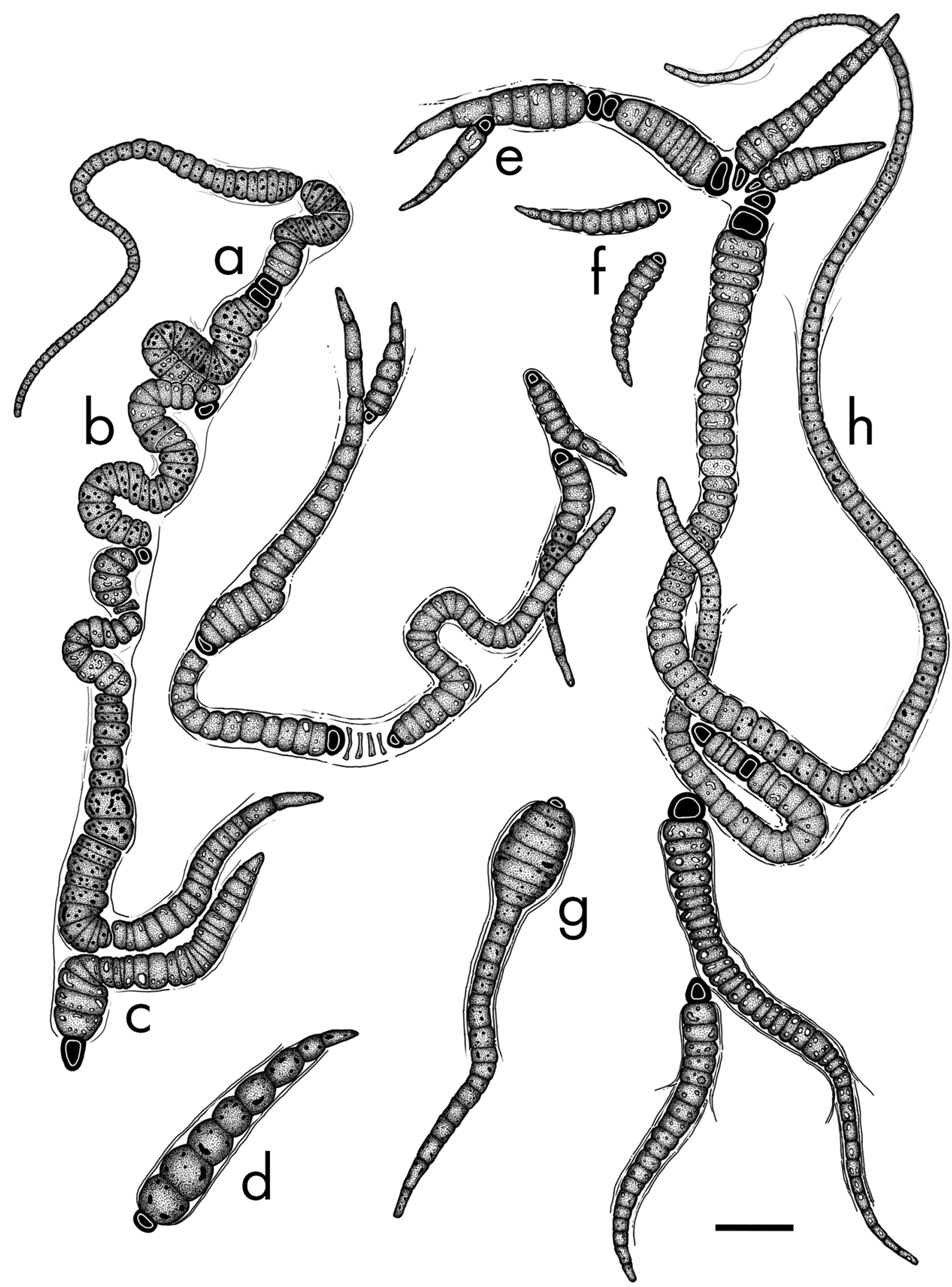

Fig. 3. Line drawing of the holotype material: (a) two heterocysts in a row; (b) geminate branching; (c) double-false branching; (d) short mature filament; (e) Calothrix-like branching of the filaments; (f) short juvenile filaments; (g) onion-like swollen apical portion of the filament; (h) long mature filament. Scale bar is $10 \mu \mathrm{m}$. 
NR_074282 Gloeobacter violaceus PCC7421

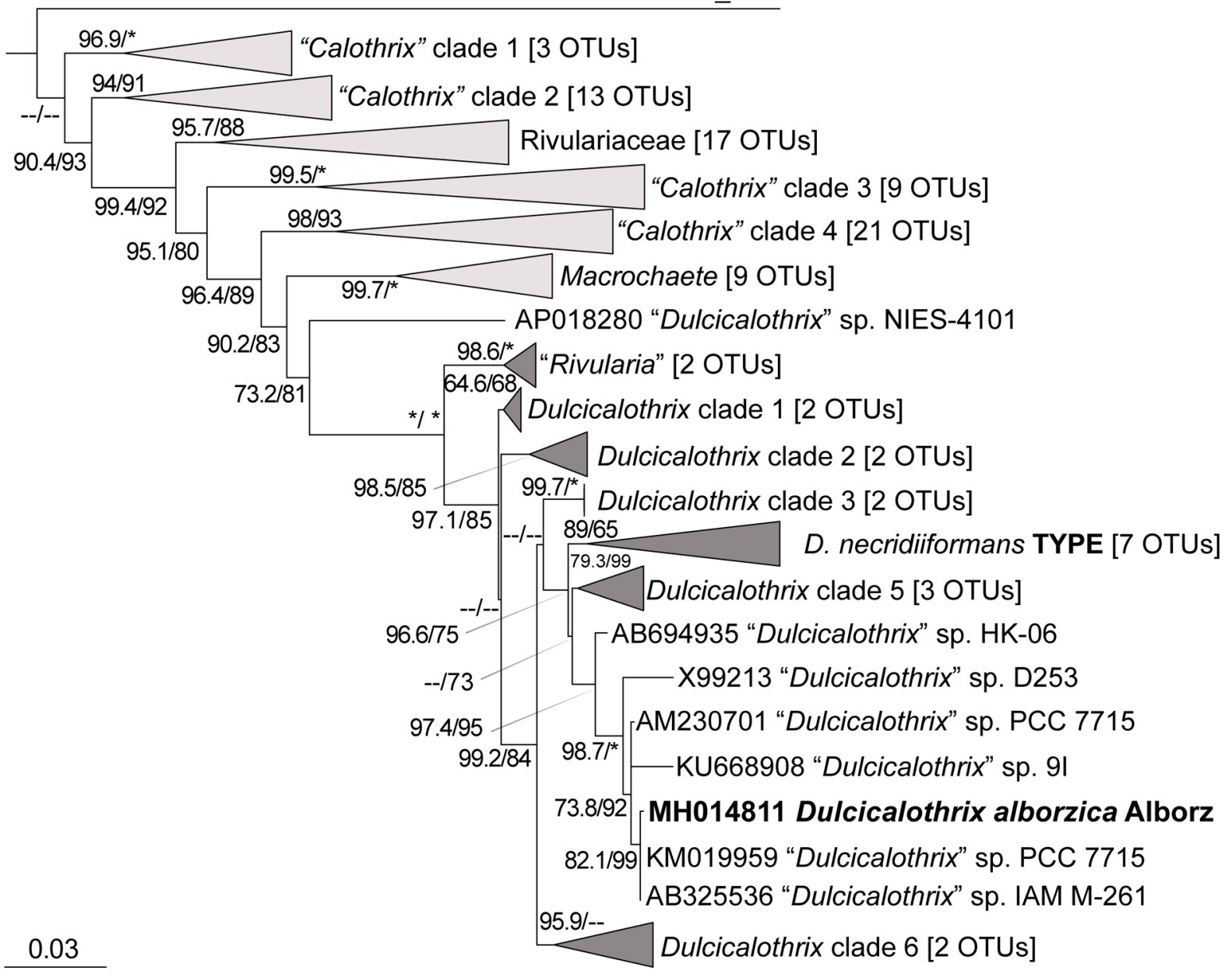

Fig. 4. Phylogenetic relationships between Dulcicalothrix alborzica Alborz and related cyanobacteria based on 16S rRNA sequences with Gloeobacter violaceus PCC7421 as out-group. Numbers near nodes indicate standard bootstrap support (\%)/ultrafast bootstrap support (\%) for ML analyses. Symbol "*” is showing 100\% support, "- " no support. Taxa in parenthesis in need to be revised.

the 16S rRNA phylogeny enclosed into Dulcicalothrix clade, which confirmed our taxonomic evaluation of the new strain. RpoC1 phylogeny contained fewer sequences from Dulcicalothrix clade compared to rbcL, nevertheless our strain clustered with the sequences from the Dulcicalothrix clade which were also found on 16S rRNA phylogeny: Dulcicalothrix sp. NIES4105 (AP018290), Dulcicalothrix sp. NIES-4071 (AP018255) (Fig. 6, Fig. S3). Overall, all three phylogenies were different in terms of taxon sampling and distribution of the major clades, however all of them grouped Dulcicalothrix sequences in one united clade including our new species D. alborzica.

It was impossible to infer a $16 \mathrm{~S}-23 \mathrm{~S}$ ITS phylogeny because many taxa in the NCBI lack sequences for that region and due to differences in the sequences within Dulcicalothrix: no tRNA operon versus both tRNAs. Nevertheless, simple compartive analysis of separate ITS structures was performed (Fig. 7). D1-D1' helices were the most similar across selected sequences as previously shown for other cyanobacteria (BECERRA-ABSALON et al. 2020). Most of the sequences in the Dulcicalothrix clade had a distinctive D1-D1' stem (5'-GACCU:AGGUC-3') except Dulcicalothrix sp. HA4186-MV5 with longer stem (5'-GACCUA:UAGGUC-3'). D1-D1' helix of the $D$. alborzica Alborz had a unique bilateral bulge in the middle of the D1-D1' structure (5'GUAAU:AAAAACC-3'). D1-D1' from $D$. parietina 102-2A was the closest to our strain, with an identical terminal loop (Fig. 7). Interestingly, all sequences had typical branching helices on the 3 ' side of the unilateral basal bulge, alternatively this structure shown as standard side loop in SARAF et al. (2019). Box-B structures of the selected Dulcicalothrix species have shown more differences than D1-D1' helices. Box-B helix of the $D$. alborzica Alborz had a large terminal loop, which was not typical for the rest of the species (Fig. 7, second line). Box-B structures were found to be quite divergent within the selected set of taxa, however all of them had the usual terminal stem (5'AGCA:UGCU-3'). 16S-23S ITS analysis have shown that both sequence and secondary structures of the $D$. alborzica Alborz are quite unique and the erection 


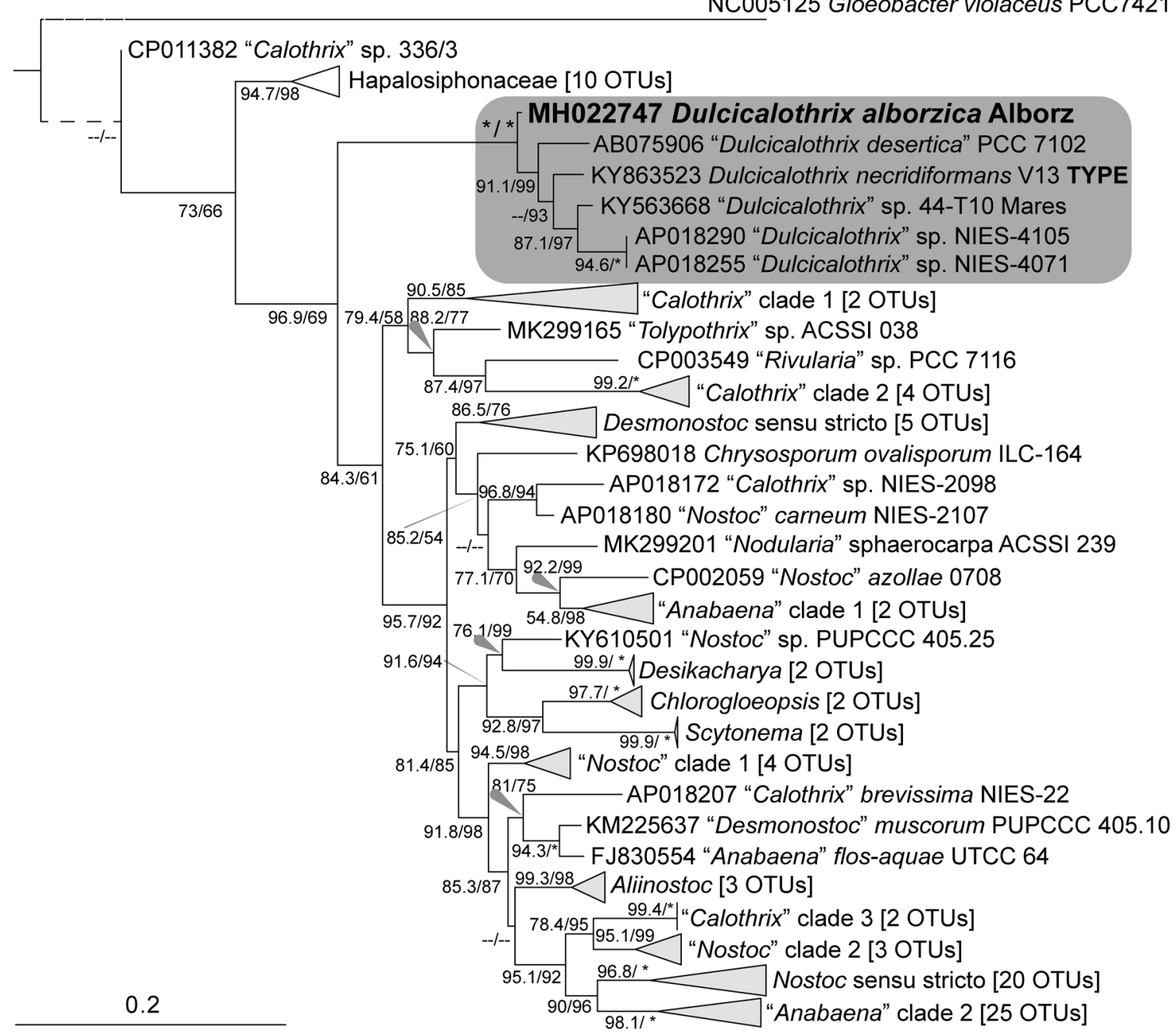

Fig. 5. Phylogenetic relationships between Dulcicalothrix alborzica Alborz and related cyanobacteria based on rbcL sequences with Gloeobacter violaceus PCC7421 as out-group. Numbers near nodes indicate standard bootstrap support and ultrafast bootstrap support for ML analyses. Symbol "*" is showing 100\% support, "_" no support. Taxa in parenthesis in need to be revised.

of a new species is highly warranted. These findings were in congruence with geography, habitat, morphology and multiple phylogenies. Additionally, information on the length of the conserved domains of many Dulcicalothrix species may be found in the Supporting Information: Table S5.

There have been recent significant advances in the systematics of the order Nostocales, with the description of many new taxa (ZAPOMĚLOVÁ et al. 2010; GALHANo et al. 2011; Werner et al. 2012; KrIENITZ et al. 2013; Mishra et al. 2015; HentschKe et al. 2016). Many more nostocalean cyanobacteria have been found in various aquatic ecosystems (Jöhnk et al. 2011). However, in Iran, polyphasic studies of cyanobacteria are still scarce and limited to phylogenetic investigations of genes encoding proteins involved in the biosynthesis of bioactive compounds in paddy fields and fresh waters (Nowruzi et al. 2006, 2012, 2017, 2018; Nowruzi \& Blanco 2019; Nowruzi \& LORENZI 2021). Additionally, some thermophilic cyanobacteria isolated from radioactive springs were investigated by HEIDARI et al. (2013, 2018).

Many sequences assigned to Calothrix in the NCBI were included in our 16S rRNA phylogeny. Even though Calotrichaceae was established by SARAF et al. (2019), authors did not possess sequences of the type species of the genus, thus this taxonomic group is still highly problematic. To fix this problem type species of the Calothrix have to be sequenced. For now "Calothrix" lineages formed up to 10 different phylogenetically distant clades showing signs of cryptic diversity. Overall clade distribution in this research was congruent with previous studies (BERRENDERO Gómez et al. 2016; GonzÁLEZ-RESENDIZ et al. 2018; SHALYGIN et al. 2018).

$\mathrm{RbcL}$ and rpoC1 genes have been reported by many researchers to be an informative marker for assessing the phylogeny and diversity of cyanobacteria (GUGGER et al. 2002; HongMeI et al. 2005; JoHANSEN \& Casamatta 2005; TATOn et al. 2006; ŘEhÁKová et al. 2007; SiEgESMUND et al. 2008; THOMAZEAU et al. 2009; ShaLygin et al. 2017). For example, phylogeny of 
U52340 Gloeobacter violaceus PCC 7421

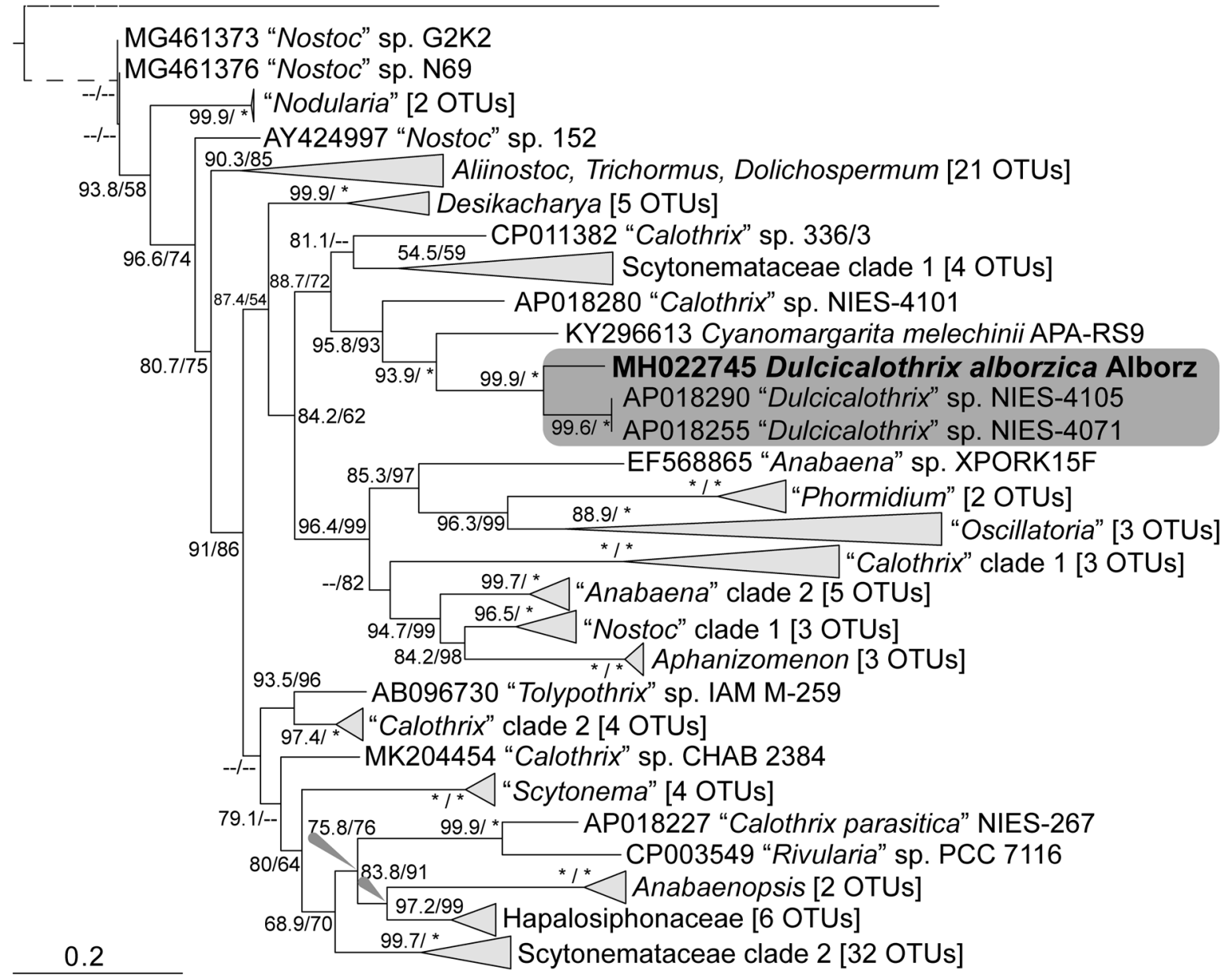

Fig. 6. Phylogenetic relationships between Dulcicalothrix alborzica Alborz and related cyanobacteria based on rpoC1 sequences with Gloeobacter violaceus PCC7421 as out group. Numbers near nodes indicate standard bootstrap support and ultrafast bootstrap support for ML analyses. Symbol "*” is showing 100\% support, "_-" no support. Taxa in parenthesis in need to be revised.

Cyanomargarita based on a maximum of 600 nucleotides from the rbcLX region was in agreement with the result of this study (SHALYGIN et al. 2017). Moreover, we observed that, to date, only few Calotrichaceae protein-coding genes sequences have been deposited in GenBank, this highlights the importance of studying these genes not only for deciphering the heterogeneity within Dulcicalothrix strains but also to resolve overall complexities associated with cyanobacterial taxonomy (ROESELERS et al. 2007).

It is commonly reported that the secondary structures of the $16 \mathrm{~S}-23 \mathrm{~S}$ ITS region helps in demarcating closely related cyanobacterial species (JOHANSEN \& CASAMATTA 2005; ŘEHÁKOvá et al. 2007). In addition to our multiple phylogenies of $D$. alborzica, we performed an analysis of the secondary structure of the $16 \mathrm{~S}-23 \mathrm{~S}$ ITS region in order to confirm the findings obtained from the phylogenetic characterization. Clear differences between the secondary structures of D. alborzica and other closely related, misidentified Calothrix strains were observed (Fig. 7), which further supports the designation of the analyzed strain as a distinct species.
The polyphasic approach has been strongly criticized by some microbiologists (HERDMAN \& RIPPKA 2021), suggesting that additional molecular information such as analysis of ITS region is not clearly separating closely related taxa. However, many new taxa are described each year with the application of $16 \mathrm{~S}-23 \mathrm{~S}$ ITS phylogeny (CASAMATTA et al. 2020; CAI et al. 2020; DAVYDOV et al. 2020). In our opinion, thorough ecological description should be followed by morphological assessment, with subsequent phylogenies, maybe even megaphylogenies as described in ZIMBA et al. (2021), finally, ITS analysis may be utilized.

\section{ACKNOWLEDGEMENTS}

We acknowledge Islamic Azad University for the financial support needed to carry out this research. We also thank Dr. Guilherme Scotta Hentschke for constructive suggestions that improved this manuscript. Addition thanks is to Cory B. Gargas for English editing.

\section{REFERENCES}

ANAGNOSTIDIS, K. \& KomÁReK, J. (1985): Modern approach 


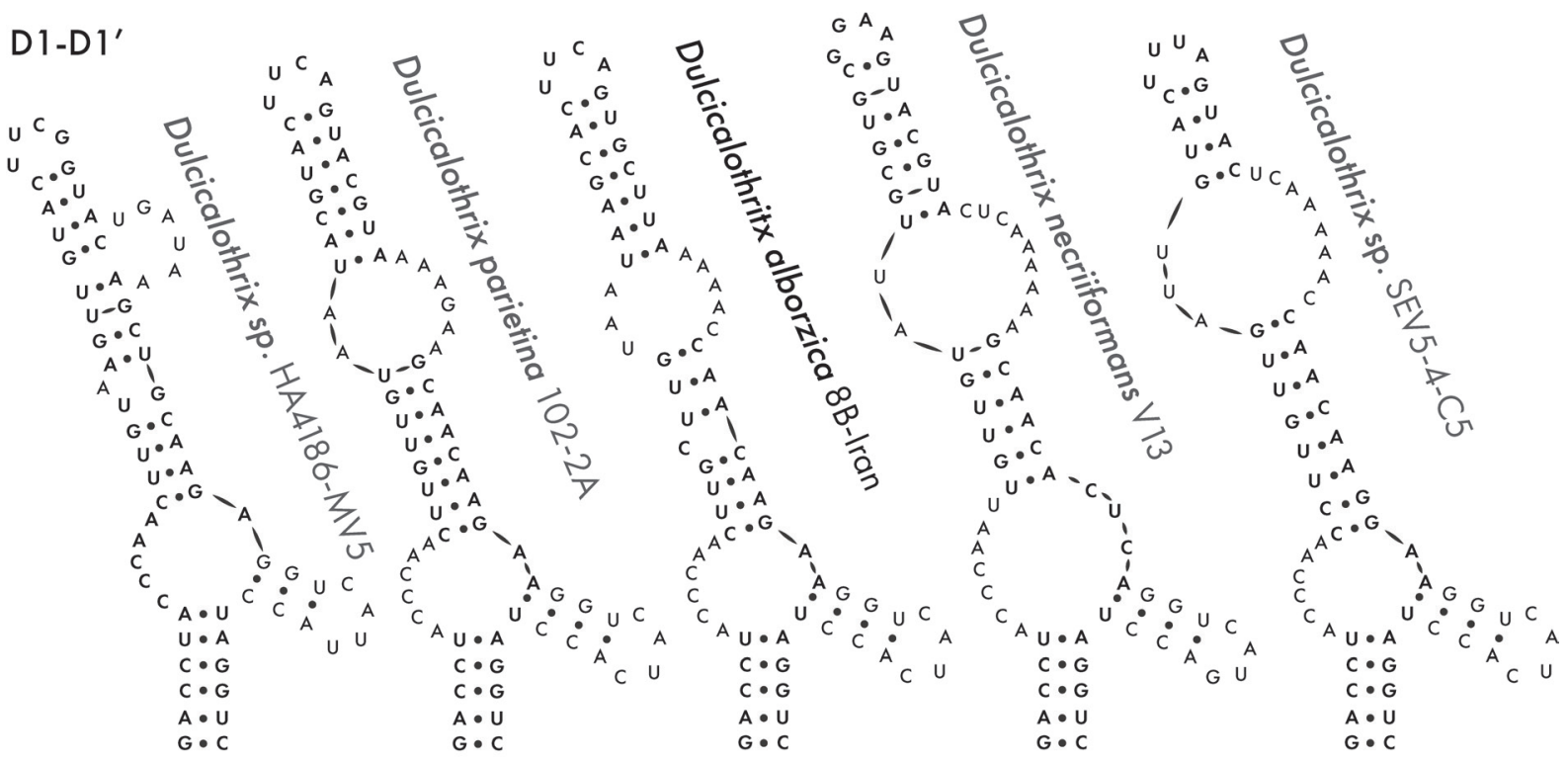

Box-B

\begin{tabular}{|c|c|}
\hline A & A A \\
\hline A & $\begin{array}{l}U \\
\end{array}$ \\
\hline$A \bullet U$ & $U \cdot A$ \\
\hline$A \bullet U$ & $A \cdot U$ \\
\hline$U \cdot A$ & $U \cdot A$ \\
\hline$U \cdot A$ & $U \cdot A$ \\
\hline$G \cdot C$ & $G \cdot C$ \\
\hline A & $C \cdot G$ \\
\hline$A \cdot U$ & U \\
\hline$A \cdot U$ & $G-U$ \\
\hline$U \cdot A$ & $U \cdot A$ \\
\hline$C \cdot G$ & $C \cdot G$ \\
\hline A & A \\
\hline$A \cdot U$ & $A \cdot U$ \\
\hline$C \cdot G$ & $C \cdot G$ \\
\hline$G \bullet C$ & $G \cdot C$ \\
\hline$A \bullet U$ & $A \bullet U$ \\
\hline
\end{tabular}
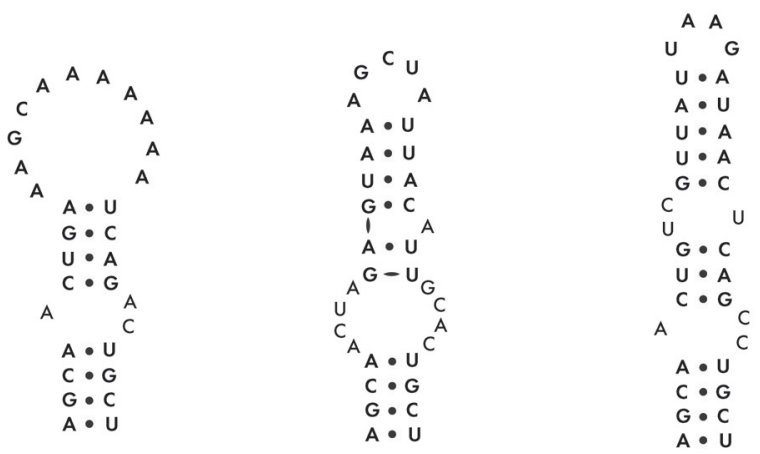

Fig. 7. Predicted secondary structures of the 16S-23S ITS region. First line depicts D1-D1' helices; second line is showing Box-B.

to the classification system of cyanophytes. 1 Introduction. - Algological Studies 38/39: 291-302.

Becerra-Absalón, I.; Johansen, J.R.; Osorio-Santos, K. \& Montejano, G. (2020): Two new Oculatella (Oculatellaceae, Cyanobacteria) species in soil crusts from tropical semi-arid uplands of México. - Fottea 20: $160-70$.

Berrendero Gómez, E.; Johansen, J.R.; KaŠtovskÝ, J.; BOHUNICKÁ, M. \& ČAPKOVÁ, K. (2016): Macrochaete gen. nov.(Nostocales, Cyanobacteria), a taxon morphologically and molecularly distinct from Calothrix. - J. Phycol. 52: 638-55.

Berrendero, E.; Perona, E. \& Mateo, P. (2008): Genetic and morphological characterization of Rivularia and Calothrix (Nostocales, Cyanobacteria) from running water. - Int. J. Syst. Evol. Microbiol. 58: 447-60.

Berrendero, E.; Perona, E. \& Mateo, P. (2011): Phenotypic variability and phylogenetic relationships of the genera Tolypothrix and Calothrix (Nostocales, Cyanobacteria) from running water. - Int. J. Syst. Evol. Microbiol. 61: 3039-51.

CAI, F.; Peng, X. \& LI, R. (2020): Violetonostoc minutum gen. et sp. nov. (Nostocales, Cyanobacteria) from a rocky substrate in China. - Algae 35: 1-16.

Casamatta, D.A.; Villanueva, C.D.; Garvey, A.D.; Stocks, H.S.; Vaccarino, M.; Dvořák, P.; Hašler, P. \& JohANSEn, J.R. (2020): Reptodigitus chapmanii (Nostocales, Hapalosiphonaceae) gen. nov.: a unique nostocalean (Cyanobacteria) genus based on a polyphasic approach. - J. Phycol. 56: 425-36.

Castenholz, R. W. \& Norris, T. B. (2005): Revisionary concepts of species in the Cyanobacteria and their applications. - Algological Studies 117: 53-69.

Davydov, D.; Shalygin, S. \& Vilnet, A. (2020): New cyanobacterium Nodosilinea svalbardensis sp. nov. (Prochlorotrichaceae, Synechococcales) isolated from alluvium in Mimer river valley of the Svalbard archipelago. - Phytotaxa 442: 61-79.

Desikachary, T. V. (1959): Cyanophyta. - 686 pp., New Delhi: Indian Council of Agricultural Research.

EdGAR, R. C. (2004): MUSCLE: multiple sequence alignment with high accuracy and high throughput. Nucl. Acids Res. 32: 1792-7.

Galhano, V.; De Figueiredo, D.R.; Alves, A.; Correia, A.; Pereira, M.J.; Gomes-Laranjo, J. \& Peixoto, F. (2011): Morphological, biochemical and molecular 
characterization of Anabaena, Aphanizomenon and Nostoc strains (Cyanobacteria, Nostocales) isolated from Portuguese freshwater habitats. - Hydrobiologia 663: 187-203.

Garcia-Pichel, F.; Loza, V.; Marusenko, Y.; Mateo, P. \& PotrafKa, R.M. (2013): Temperature drives the continental-scale distribution of key microbes in topsoil communities. - Science 340: 1574-7.

González-Resendiz, L.; Johansen, J.R.; Alba-Lois, L.; Segal-Kischinevzky, C.; Escobar-SAncheZ, V.; Jimenez Garcia, L.F.; Hauer, T. \& LeóNTEJERA, H. (2018): Nunduva, a new marine genus of Rivulariaceae (Nostocales, Cyanobacteria) from marine rocky shores. - Fottea 18: 86-105.

Gould, S. B.; Waller, R. F. \& McFadden, G. I. (2008): Plastid evolution. - Ann. Rev. Plant Biol. 59: 491-517.

Gugger, M.; Lyra, C.; Henriksen, P.; Coute, A.; Humbert, J.F. \& Sivonen, K. 2002. Phylogenetic comparison of the cyanobacterial genera Anabaena and Aphanizomenon. - Int. J. Syst. Evol. Microbiol. 52: 1867-80.

Heidari, F.; Riahi, H.; Yousefzadi, M. \& Shariatmadari, Z. (2013): Morphological and phylogenetic diversity of cyanobacteria in four hot springs of Iran. - Iran. J. Bot. 19: 162-72.

Heidari, F.; Zima, J.; Riahi, H. \& Hauer, T. (2018): New simple trichal cyanobacterial taxa isolated from radioactive thermal springs. - Fottea 18: 137-49.

Hentschie, G. S.; Johansen, J. R.; Piestrasiak, N.; Fiore, M. F.; Rigonato, J.; Sant’Anna, C. L. \& KomáreK, J. (2016): Phylogenetic placement of Dapisostemon gen. nov. and Streptostemon, two tropical heterocytous genera (Cyanobacteria). - Phytotaxa 245:129-43.

HERDMAN M. \& RiPPKA R. (2021): Cyanobacterial phylogenetic tree. - http://cyanophylogeny.scienceontheweb. net

HoffMAnN, L.; KomÁREK, J. \& KaŠTovskỳ, J. (2005): System of cyanoprokaryotes (Cyanobacteria) - state in 2004. - Algological Studies 117: 95-115.

Hongmei, J.; Aitchison, J.C.; LaCAP, D.C.; PeerapornPisal, Y.; Sompong, U. \& Pointing, S.B. (2005): Community phylogenetic analysis of moderately thermophilic cyanobacterial mats from China, the Philippines and Thailand. - Extremophiles 9: 325-32.

Johansen, J. R. \& Casamatta, D. A. (2005): Recognizing cyanobacterial diversity through adoption of a new species paradigm. - Algological Studies 117: 71-93.

Johansen, J.R.; KovaciK, L.; Casamatta, D.A.; Iková, K.F. \& KaŠTovSKÝ, J. (2011): Utility of 16S-23S ITS sequence and secondary structure for recognition of intrageneric and intergeneric limits within cyanobacterial taxa: Leptolyngbya corticola $\mathrm{sp}$. nov.(Pseudanabaenaceae, Cyanobacteria). - Nova Hedwigia 92: 283-302.

Jöhnk, K.D.; BRÜGGEMANN, R.; Rücker, J.; Luther, B.; Simon, U.; Nixdorf, B. \& Wiedner, C. (2011): Modelling life cycle and population dynamics of Nostocales (cyanobacteria). - Environ. Model. Softw. 26: 669-77.

KomÁREK, J. \& KAŠTOVSKÝ, J. (2003): Coincidences of structural and molecular characters in evolutionary lines of cyanobacteria. - Algological Studies 109: 305-25.
KomÁreK, J. (2013): Cyanoprokaryota: 3. Teil: Heterocytous Genera. - In: Büdel, B.; Gärtner, G.; KrienitZ, L. \& Schagerl, M. (eds): Süßwasserflora von Mitteleuropa, Bd. 19/3. - 1130 pp., Springer Specktrum, Berlin.

KomáreK, J.; Kaštovský, J.; Mareš, J. \& Johansen, J.R. (2014): Taxonomic classification of cyanoprokaryotes (cyanobacterial genera) 2014, using a polyphasic approach. - Preslia 86: 295-335.

Krienitz, L.; Dadheech, P. K. \& Kotut, K. (2013): Mass developments of the cyanobacteria Anabaenopsis and Cyanospira (Nostocales) in the soda lakes of Kenya: ecological and systematic implications. Hydrobiologia 703: 79-93.

Kumar, S.; Stecher, G.; Li, M.; Knyaz, C.; Tamura, K. \& BATTistuZzI, F. U. (2018): MEGA X: molecular evolutionary genetics analysis across computing platforms. - Mol. Biol. Evol. 35: 1547-1549.

Mareš, J.; STRUNECKÝ, O.; BuČINSKÁ, L. \& Wiedermannová, J. (2019): Evolutionary Patterns of Thylakoid Architecture in Cyanobacteria. - Front. Microbiol. $10: 1-22$.

Minh, B.Q.; Nguyen, M.A.T. \& von Haeseler, A. (2013): Ultrafast approximation for phylogenetic bootstrap. - Mol. Biol. Evol. 30: 1188-1195.

Mishra, S.; Bhargava, P.; Adhikary, S.P.; Pradeer, A. \& RAI, L.C. (2015): Weighted morphology: a new approach towards phylogenetic assessment of Nostocales (Cyanobacteria). - Protoplasma 252: $145-163$

Nguyen, L.T.; Schmidt, H.A.; Von Haeseler, A. \& Minh, B.Q. (2015): IQ-TREE: a fast and effective stochastic algorithm for estimating maximum-likelihood phylogenies. - Mol. Biol. Evol. 32: 268-274.

Nowruzi, B. \& Ahmadimoghadam, A. (2006): Two new records of heterocystus cyanobacteria (Nostocaceae) from paddy fields of Golestan Province. - Iran. J. Bot. 11: 170-173.

Nowruzi, B. \& Blanco, S. (2019): In silico identification and evolutionary analysis of candidate genes involved in the biosynthesis methylproline genes in cyanobacteria strains of Iran. - Phytochem. Lett. 29: 199-211.

Nowruzi, B. \& LoREnzI, A.S. (2021): Characterization of a potentially microcystin-producing Fischerella sp. isolated from Ajigol wetland of Iran. - S. Afr. J. Bot. 137: 423-33.

Nowruzi, B.; Blanco, S. \& Nejadsattari, T. (2018): Chemical and molecular evidences for the poisoning of a duck by anatoxin-a, nodularin and cryptophycin at the coast of Lake Shoormast (Mazandaran province, Iran). - Int. J. Algae. 20: 359-76.

Nowruzi，B.; Khavari-Nejad，R.A.; NeJadsattari，T.; Sivonen, K. \& Fewer, D. (2017): A proposal for the unification of two cyanobacterial strains of Nostoc as the same species. - Rostaniha 17: 161-72.

Nowruzi, B.; Khavari-Nejad, R.A.; Sivonen, K.; Kazemi, B.; Najafi, F. \& Nejadsattari, T. (2012): Identification and toxigenic potential of a Nostoc sp. - Algae 27: 303-13.

Řeháková, K.; Johansen, J.R.; Casamatta, D.A.; Xuesong, L. \& Vincent, J. (2007): Morphological and molecular characterization of selected desert soil cyanobacteria: three species new to science including Mojavia pulchra gen. et sp. nov. - Phycologia 46: 481-502. 
Rippka, R.; Deruelles, J.; Waterbury, J.B.; Herdman, M. \& STANIER, R.Y. (1979): Generic assignments, strain histories and properties of pure cultures of cyanobacteria. - Microbiology 111: 1-61.

Roeselers, G.; Stal, L.J.; van Loosdrecht, M.C. \& MuYzer, G. (2007): Development of a PCR for the detection and identification of cyanobacterial nifD genes. - J. Microbiol. Methods 70: 550-556.

Saraf, A.; Suradkar, A.; Dawda, H.G.; Gaysina, L.A.; Gabidullin, Y.; Kumat, A.; Behere, I.; Kotulkar, M.; Batule, P. \& Singh, P. (2019): Phylogenetic complexities of the members of Rivulariaceae with the re-creation of the family Calotrichaceae and description of Dulcicalothrix necridiiformans gen nov., sp nov., and reclassification of Calothrix desertica. - FEMS Microbiol. Lett. 366: p.fnz219.

Shalygin, S.; Pietrasiak, N.; Gomez, F.; Mlewski, C.; Gerard, E. \& JohANSEn, J.R. (2018): Rivularia halophila sp. nov. (Nostocales, Cyanobacteria): the first species of Rivularia described with the modern polyphasic approach. - Eur. J. Phycol. 53: 537-548.

Shalygin, S.; Shalygina, R.; Johansen, J.R.; Pietrasiak, N.; Berrendero Gómez, E.; BohunickÁ, M.; MAREš, J. \& SheIL, C.A. (2017): Cyanomargarita gen. nov.(Nostocales, Cyanobacteria): convergent evolution resulting in a cryptic genus. - J. Phycol. 53: 762-777.

Siegesmund, M.A.; Johansen, J.R.; Karsten, U. \& Friedl, T. (2008): Coleofasciculus gen. nov.(Cyanobacteria): morphological and molecular criteria for revision of the genus Microcoleus Gomont. - J. Phycol. 44: $1572-1585$.

Sihvonen, L.M.; Lyra, C.; Fewer, D.P.; RajaniemiWacklin, P.; LehtimÄKi, J.M.; Wahlsten, M. \& Sivonen, K. (2007): Strains of the cyanobacterial genera Calothrix and Rivularia isolated from the Baltic Sea display cryptic diversity and are distantly related to Gloeotrichia and Tolypothrix. - FEMS Microbiol. Ecol. 61: 74-84.

Taton, A.; Grubisic, S.; Ertz, D.; Hodgson, D.A.; Piccardi, R.; Biondi, N.; TRedici, M.R.; Mainini, M.; Losi, D.; Marinelli, F. \& Wilmotte, A. (2006): Polyphasic study of Antarctic cyanobacterial strains. - J. Phycol. 42: 1257-1270.

Thomazeau, S.; Houdan-Fourmont, A.; Couté, A.; Duval, C.; Couloux, A.; Rousseau, F. \& Bernard, C. (2009): The contribution of sub-Saharan African strains to the phylogeny of cyanobacteria: focusing on the Nostocaceae family (Nostocales, Cyanobacteria). - J. Phycol. 46: 564-579

Turland, N.J.; Wiersema, J.H.; Barrie, F.R.; Greuter, W.; Hawksworth, D.L.; Herendeen, P.S.; Knapp, S.; KuSBER, W.-H.; LI, D.-Z.; MARHOLD, K.; MAY, T.W.; McNeill, J.; Monro, A.M.; Prado, J.; Price, M.J. \& Sмith, G.F. (eds.) (2018): International Code of Nomenclature for algae, fungi, and plants (Shenzhen Code) adopted by the Nineteenth International Botanical Congress Shenzhen, China, July 2017. Regnum Vegetabile. - 159 pp., Koeltz Botanical Books, Glashütten.

Werner, V.R.; Laughinghouse IV, H.D.; Fiore, M.F.; Sant'Anna, C.L.; Hoff, C., De Souza Santos, K.R.; Neuhaus, E.B.; Molica, R.J.R.; Honda, R.Y. \& ECHENIQUE, R.O. (2012): Morphological and molecular studies of Sphaerospermopsis torques-reginae
(Cyanobacteria, Nostocales) from South American water blooms. - Phycologia 51: 228-38.

Wilmotte, A. \& Golubic, S. (1991): Morphological and genetic criteria in the taxonomy of Cyanophyta Cyanobacteria. - Arch. Hydrobiol. 92: 1-24.

Wilmotte, A. (1994): Molecular Evolution and Taxonomy of the Cyanobacteria. - In: Bryant, D. A. (ed.): The Molecular Biology of Cyanobacteria. - pp. 1-25, Springer, Dordrecht.

ZapomĚLová, E.; ŘeHÁKovÁ, K.; JeZberová, J. \& KomÁRKovÁ, J. (2010): Polyphasic characterization of eight planktonic Anabaena strains (Cyanobacteria) with reference to the variability of 61 Anabaena populations observed in the field. - Hydrobiologia 639: 99-113.

Zimba, P.V.; Shalygin, S.; Huang, I.S.; MomČılović, M. \& Abdulla, H. (2021): A new boring toxin producerPerforafilum tunnelli gen. \& sp. nov. (Oscillatoriales, Cyanobacteria) isolated from Laguna Madre, Texas, USA. - Phycologia 60: 10-24

ZuKer, M. (2003): Mfold web server for nucleic acid folding and hybridization prediction. - Nucl. Acids Res. 31: 3406-15.

Supplementary material

The following supplementary material is available for this article:

Fig. S1. Uncollapsed 16S rRNA phylogeny showing position of Dulcicalothrix alborzica.

Fig. S2. Uncollapsed rpoC1 phylogeny showing position of Dulcicalothrix alborzica.

Fig. S3. Uncollapsed rbcL phylogeny showing position of Dulcicalothrix alborzica.

Table S1. Limnological parameters of the sample site.

Table S2. Target genes and oligonucleotide primers used in this study.

Table S3. Accession numbers of Sequence data deposited in the DNA Data Bank of Japan.

Table S4. Morphological characteristics of the Dulcicalothix alborzica.

Table S5. Comparison of the nucleotides length of the ITS regions of Dulcicalothrix alborzica with reference strains.

This material is available as part of the online article (http:// fottea.czechphycology.cz/contents)

(C) Czech Phycological Society (2021)

Received January 10, 2021

Accepted May 6, 2021 